\title{
Hubungan antara Efikasi Diri dan Kecenderungan Kambuh pada Pecandu Narkoba yang Menjalani Rehabilitasi di Yogyakarta
}

\author{
Intan Agitha Putri \\ Yulianti Dwi Astuti \\ Prodi Psikologi, Fakultas Psikologi dan Ilmu Sosial Budaya, Universitas Islam Indonesia, \\ Yogyakarta
}

\begin{abstract}
This study aims to examine whether there is a negative relationship between selfefficacy and the tendency of efficacy in drug addicts undergoing rehabilitation. The subjects in this study were 59 drug addicts who were undergoing the recovery process (hospitalization and outpatient care) in a drug rehabilitation centers in Yogyakarta. This study uses a scale of selfefficacy compiled by Noviza (2008) and modified by researchers based on aspects of self-efficacy Corsini (1994). While the Relapse Tendency scale uses a scale from Rozi (2016) that modified researchers referring to the relapse stages of Gorski and Miller (1986). Data analysis using product moment correlation technique shows the value of $r=-0.352(p=0.006)$, which means there is a significant negative relationship between self-efficacy and the relapse tendency in drug addicts undergoing rehabilitation.
\end{abstract}

Keywords: drug addicts, relapse tendency, self-efficacy

Abstrak. Penelitian ini bertujuan untuk menguji apakah ada hubungan negatif antara efikasi diri dan kecenderungan kambuh pada pecandu narkoba yang menjalani rehabilitasi. Subjek dalam penelitian ini adalah 59 pecandu narkoba yang sedang menjalani proses pemulihan (rawat inap maupun rawat jalan) di sebuah pusat rehabilitasi narkoba di Yogyakarta. Penelitian ini menggunakan skala efikasi diri yang disusun oleh Noviza (2008) dan dimodifikasi oleh peneliti berdasarkan aspek-aspek efikasi diri Corsini (1994). Sedangkan skala Kecenderungan Kambuh menggunakan skala dari Rozi (2016) yang dimodifikasi peneliti mengacu pada tahap-tahap kambuh Gorski dan Miller (1986). Analisis data menggunakan teknik korelasi Product Moment menunjukkan nilai $\mathrm{r}=-0,352(\mathrm{p}=0,006)$, yang artinya terdapat hubungan negatif yang signifikan antara efikasi diri dan kecenderungan kambuh pada pecandu narkoba yang menjalani rehabilitasi

Kata Kunci: efikasi diri, kecenderungan kambuh, pecandu narkoba

Korespondensi: Yulianti Dwi Astuti. E-mail: yulianti.dwiastuti@uii.ac.id. 
Kasus penyalahgunaan narkoba di Indonesia meningkat setiap tahunnya. Berdasarkan data Badan Narkotika Nasional (BNN) di tahun 2015, kenaikan persentase pengguna narkoba di Indonesia mencapai 40\%. Menurut kepala BNN, saat ini Indonesia berstatus darurat narkoba. Tahun 2016 lalu, tercatat bahwa kasus penyalahgunaan narkoba terjadi antara 40 sampai 50 perhari, dan sekarang naik menjadi 57 kasus perhari (Ellya, 2017). Penyalahgunaan narkoba termasuk masalah yang cukup kompleks dan memiliki dimensi yang luas, baik dari sudut medik, psikiatrik, kesehatan jiwa, maupun psikososial. Dampak dari penggunaan narkoba di antaranya dapat mengakibatkan halusinasi, seperti pada penggunaan kokain, Lysergyc Acid Diethylamide (LSD), dan amphetamine (Infodatin, 2014).

Badan Narkotika Nasional Provinsi (BNNP) Daerah Istimewa Yogyakarta (DIY) menyatakan pengguna narkoba di Yogyakarta menempati peringkat pertama di Indonesia setelah Badan Narkotika Nasional (BNN) dan Universitas Indonesia melakukan penelitian pada akhir 2016 lalu. Kebanyakan para pengguna narkoba adalah pelajar dan mahasiswa. Dari 3,6 juta penduduk DIY, sebanyak $2,6 \%$ di antaranya adalah pengguna narkoba (Hadi, 2017). Hal tersebut menunjukkan adanya tingkat prevalensi yang tinggi untuk kasus penyalahgunaan narkoba di DIY.
Penyebab seseorang menggunakan Narkotika, Psikotropika, dan Zat Adiktif Lainnya (NAPZA) menurut Hawari (dalam Afiatin, 2008) sangat kompleks. Hal tersebut merupakan interaksi antar faktor yang terkait, di antaranya adalah faktor internal individu, faktor lingkungan baik dari lingkungan keluarga, teman sebaya, sekolah, maupun lingkungan sosial atau masyarakat, serta faktor ketersediaan zat. Dapat diketahui bahwa dampak yang muncul setelah mengkonsumsi NAPZA sangat fatal, yakni selain merusak kesehatan fisik maupun psikologis penggunanya, NAPZA juga merupakan penyakit yang kronis dan mudah kambuh hingga menimbulkan kecanduan (Hawari, 1997). Lebih rinci, penelitian Hawari (1997) membuktikan bahwa penyalahgunaan NAPZA dapat merusak hubungan kekeluargaan, menurun-kan kemampuan belajar, ketidakmampuan membedakan hal yang baik dan buruk, perubahan perilaku menjadi anti sosial, meningkatkan risiko kecelakaan lalu lintas, kriminalitas, dan tindakan kekerasan lainnya.

$$
\text { Selain itu, Sasangka }
$$
menyatakan penggunaan narkoba menimbulkan efek ketergantungan baik ketergantungan fisik maupun psikologis. Ketergantungan fisik terlihat pada saat penghentian penggunaan narkoba. Penghentian penggunaan narkoba ini akan menimbulkan gejala-gejala abstinensi 
(suatu rangkaian gejala yang hebat karena pemakaian obat dihentikan). Misalnya pada obat-obatan turunan morfin akan mengakibatkan ketakutan, berkeringat, mata berair, gangguan lambung dan usus, sakit perut dan lambung, tidak bisa tidur dan sebagainya. Gejala-gejala abstinensi tersebut hanya dapat diatasi jika individu menggunakan narkoba yang sejenis. Keadaan tersebut bisa menimbulkan kematian. Rasa khawatir yang mendalam akan timbulnya gejala-gejala abstinensi mendorong seseorang menggunakan narkoba lagi.

Tidak hanya masalah penyalahgunaan NAPZA yang sangat memprihatinkan dan butuh penyelesaian, tetapi permasalahan yang sering terjadi pada pengguna NAPZA ialah terjadinya kambuh. Kambuh merupakan permasalahan yang rumit dan butuh penanggulangan intensif. Sebagian besar penyalahguna narkoba memiliki potensi untuk kambuh. Kambuh atau kambuh akan narkoba merupakan suatu tantangan yang tak terpisahkan dari proses panjang menuju kesembuhan penuh. Walaupun mantan pengguna sudah dapat lepas dari ketergantungan narkoba untuk jangka waktu tertentu, tetapi kecenderungan untuk menggunakan zat-zat tersebut atau yang biasa disebut sugesti dapat terjadi secara mendadak dan tak terkendalikan, terutama pada saat suasana hati terganggu/kacau. Oleh sebab itu, banyak ahli berpendapat bahwa sugesti untuk kambuh adalah bagian dari penyakit ketergantungan (Infodatin, 2014). Menurut Eka (dalam Jhonny, 2009), pengguna narkoba yang mengalami kambuh biasanya tidak mampu menghilangkan sugesti akibat penggunaan obat-obatan dan kurangnya dukungan yang kuat dari keluarga dan lingkungannya untuk dapat bebas dari zat narkoba, serta ditambah dengan lamanya waktu pengguna mengalami ketergantungan.

Menurut BNN (2007), kekambuhan dengan narkoba merupakan sebuah proses dari ketidakmampuan individu untuk berhadapan dengan hidup dan biasanya terlihat adanya perubahan ke arah kemunduran dari faktor gaya hidup, keterampilan dalam menyelesaikan masalah, emosi, sistem kepercayaan, dan penempatan diri. Apabila individu tidak mampu keluar dari permasalahan yang dihadapi maka individu akan kembali menggunakan NAPZA dengan dosis yang lebih tinggi dan jenis yang lebih beragam. Hal ini sesuai dengan pernyataan Bisono (2008) bahwa individu yang menggunakan narkoba biasanya merupakan sebuah akibat. Keadaan yang tidak kondusif yang menjadi penyebab pengguna narkoba menjadi rapuh, kecewa, dan berakibat pada penggunaan narkoba. Sehingga fenomena pengguna narkoba yang kembali kambuh semakin meningkat tanpa adanya penyelesaian yang tepat terhadap permasalahan yang dihadapi. 
Berdasarkan data dari Departemen Sosial (Media Indonesia, 2008), setiap tahun terdapat $20 \%$ hingga $50 \%$ mantan pengguna NAPZA yang mengalami kambuh. Salah satu faktor penyebabnya ialah para pengguna narkoba hanya ditangani secara medis, tanpa dibina secara sosial di panti rehabilitasi. Walaupun telah lepas dari ketergantungan obat, jika pengguna tidak diberi bekal membaur kembali di masyarakat dan keluarga, maka dalam jangka waktu satu sampai dua bulan mereka akan kembali mengonsumsi narkoba. Selain itu, Direktur Pasca Rehabilitasi Deputi Bidang Rehabilitasi BNN, menyatakan bahwa tingkat kekambuhan mantan pecandu narkoba di Indonesia tinggi. Dari sekitar 6.000 pecandu yang ikut menjalani rehabilitasi pertahunnya, sekitar 40 persennya akhirnya kembali lagi menjadi pecandu dikarenakan usai sembuh masyarakat tidak mau menerima mantan pecandu narkoba, mencari kerja susah, dan tidak ada kegiatan. Mantan pecandu narkoba stres dan akhirnya kembali ke pergaulan lama dan kembali menjadi pecandu (Ariwibowo, 2013). Dapat diprediksikan bahwa dari sepertiga sampai setengah jumlah pasien akan cenderung kembali menggunakan zat terlarang setidaknya sekali dalam 12 bulan masa pengobatan. Berdasarkan data BNN (2007), angka kekambuhan narkoba di Indonesia mencapai 90\%, yakni 9 dari 10 pecandu yang menjalani program rehabilitasi kembali mengkonsumsi narkoba.

Berdasarkan hasil wawancara yang dilakukan peneliti dengan salah satu konselor NAPZA di Rumah Sakit Jiwa Ghrasia, dapat diketahui bahwa 70\% pecandu narkoba yang menjalani rehabilitasi di Rumah Sakit Jiwa Ghrasia mengalami kambuh atau kembali mengkonsumsi narkoba setelah program rehabilitasi berakhir. Hal ini dapat dilihat dari pengalaman mereka sebelumnya yang 3 atau 4 kali keluar masuk rehabilitasi, bahkan ada pecandu yang sampai 10 kali keluar masuk rehabilitasi. Biasanya, pecandu yang mengalami kambuh disebabkan oleh suasana hati yang kurang baik, rendahnya efikasi diri, tekanan dari lingkungan (stresor), dan lingkungan pasien yang masih dikelilingi oleh pengguna narkoba. Konselor tersebut mengatakan bahwa pasien yang masih menjalani hubungan secara intens dengan pengguna lain akan mudah terpancing dan menimbulkan sugesti ingin mengonsumsi narkoba lagi. Menurut Nasution, para pengguna narkoba akan merasakan beberapa hal sebagai akibat dari lapse, salah satunya yaitu kembali menggunakan narkoba dalam jumlah banyak sebagai tindakan pembalasan akan rasa rindunya menggunakan narkoba (Badan Narkotika Nasional, 2007). Hal tersebut apabila dibiarkan dapat berujung pada over dosis (OD) bahkan kematian bagi para pengguna 
yang kambuh.

$$
\text { Marlatt dan Gordon }
$$
mengemukakan beberapa faktor yang dapat memicu terjadinya kambuh pada pecandu narkoba. Terdapat dua kategori, yakni faktor yang berasal dari dalam diri individu (internal) maupun dari lingkungan (eksternal). Faktor internal yang dapat memicu terjadinya kambuh di antaranya yaitu efikasi diri, motivasi, keinginan tinggi untuk mengkonsumsi zat, pola koping, kondisi emosional, dan luaran yang diharapkan. Sedangkan faktor eksternal yang dapat memicu terjadinya kambuh yaitu adanya situasi sosial yang menekan dan munculnya konflik interpersonal. Selain itu, Muttaqin (2007) dalam penelitiannya tentang kambuh menjelaskan bahwa kambuh juga dipengaruhi oleh faktor jenis kelamin, tingkat pendidikan, status perkawinan, dan status pekerjaan.

Menurut Nasution, saat kembali kambuh pengguna narkoba akan merasakan beberapa akibat yang ditimbulkan ketika mereka memutuskan untuk kembali menggunakan NAPZA (Badan Narkotika Nasional, 2007). Akibat tersebut di antaranya yaitu hilangnya harapan yang telah dibangun selama masa rehabilitasi. Hal ini disebabkan saat mantan pengguna kembali menggunakan NAPZA, maka pengguna tersebut akan kembali ke titik awal. Selain itu, kambuh memicu timbulnya konflik dalam keluarga, dan dampak utama yang ditimbulkan dari kambuh adalah individu akan menggunakan NAPZA dengan jumlah yang lebih banyak sebagai tindakan pembalasan akan rasa rindunya menggunakan narkoba. Apabila hal ini dibiarkan terus menerus akan menimbulkan over dosis, bahkan kematian pada penggunanya.

Terlihat bahwa akibat yang ditimbulkan dari kambuh narkoba sangat negatif, merusak kesehatan individu, dan merusak hubungan dengan keluarga dan masyarakat, bahkan menimbulkan kematian. Sebelum kondisi itu terjadi, maka dibutuhkan proses penanganan yang tepat, sesuai dengan permasalahan yang dihadapi dan kondisi psikologis yang dirasakan para pengguna narkoba. Upaya dan keberhasilan dalam menangani pengguna narkoba yang kambuh dalam proses rehabilitasi seharusnya tidak hanya diukur dari kemampuan dalam memulihkan kondisi fisik dan psikologis pecandu, tetapi juga dari keberhasilan mengintegrasi individu kembali ke masyarakat dan hidup secara layak. Jika program yang disediakan hanya meliputi pemulihan fisik dan psikologis saja, maka program rehabilitasi bagi pengguna narkoba yang mengalami kambuh dapat dikatakan tidak efektif (Colondam, 2008).

$$
\text { Gossop (dalam Bandura, 1997) }
$$

menyatakan bahwa salah satu faktor penting yang berkaitan dengan hasil dari perawatan yang dilakukan adalah harapan dan efikasi diri dalam melawan penyalahgunaan obat-obatan. Semakin kuat efikasi diri yang ditanamkan pada diri 
individu selama proses perawatan, maka semakin tinggi tingkat keberhasilan pecandu untuk meninggalkan zat narkoba tersebut. Selain itu, Gossop (dalam Bandura, 1997) juga mengatakan bahwa efikasi diri dan dukungan suportif merupakan dua faktor yang secara konsisten menjadi prediktor yang signifikan dalam menentukan keberhasilan perawatan bagi pecandu narkoba. Corsini (1994) mengatakan bahwa efikasi diri merupakan harapan untuk mencari kesuksesan dengan hasil yang sesuai dengan usaha yang dilakukan. Harapan tersebut sebagai salah satu pendorong yang kuat, sehingga menimbulkan usaha menunjang kesuksesan seseorang. Efikasi diri meliputi proses kognitif, sosial, emosional, dan keterampilan dalam berperilaku untuk mencapai tujuan yang diinginkan.

Terkait kasus penyalahgunaan narkoba, efikasi diri lebih spesifik terkait dengan keyakinan terhadap kemampuan mencapai keberhasilan dalam menjalankan program-program rehabilitasi. Tingkat efikasi diri yang dimiliki pecandu narkoba memiliki pengaruh penting dalam penataan awal proses terapeutik. Maka dari itu, Miller dan Rollnick (dalam Bandura, 1997) mengatakan bahwa, individu yang memulai perawatan dengan efikasi diri yang rendah perlu untuk meyakinkan diri terlebih dahulu bahwa individu tersebut mampu untuk sembuh, karena jika keraguan yang ada dalam diri individu tersebut berkelanjutan dan tidak diatasi, maka dapat memengaruhi individu dalam memertahankan upaya-upaya yang dilakukan untuk mencapai keberhasilan perawatan. Secara umum, efikasi diri memiliki peranan penting dalam mendukung proses pemulihan pecandu narkoba. Marlatt dan Gordon (1985) menyatakan bahwa salah satu intervensi spesifik yang harus dilakukan untuk mencegah terjadinya kambuh adalah peningkatan efikasi diri individu pecandu narkoba. Selain dapat membantu proses pemulihan, efikasi diri juga memiliki keterkaitan dengan keinginan penggunaan kembali narkoba yang dapat memicu pecandu narkoba untuk mengalami kambuh.

Rendahnya efikasi diri memiliki keterkaitan dengan kambuh. Kondisi efikasi diri yang rendah pada pecandu narkoba telah dibuktikan melalui penelitian yang dilakukan oleh Ibrahim, Kumar, dan Samah (2011) terhadap 400 pecandu narkoba yang pernah mengalami kasus kambuh dan menunjukkan hasil bahwa $86,3 \%$ subjek memiliki level efikasi diri sedang menuju rendah. Penelitian ini juga menunjukkan bahwa $74,5 \%$ responden mengakui bahwa mereka mudah diserang pada situasi tertentu dan 53,8\% mengaku bahwa mereka merasa kurang yakin terhadap kemampuan dalam melakukan sesuatu. Selain itu, penelitian yang dilakukan oleh Torrecillas, Cobo, Delgado, dan Uclés (2015) 
dapat menjelaskan peran efikasi diri dalam memprediksi jumlah penggunaan narkoba yang dapat menimbulkan kemungkinan kambuh. Efikasi diri memiliki korelasi negatif dengan kuantitas penggunaan narkoba yang mengindikasikan bahwa peningkatan efikasi diri menurunkan kemungkinan penggunaan narkoba (Torrecillas, dkk., 2015). Hal ini memperkuat bukti bahwa efikasi diri dapat menjadi indikator terjadinya kambuh melalui tingkat kemungkinan penggunaan narkoba. Selain itu, perawatan yang diarahkan pada peningkatan efikasi diri pecandu narkoba, dinilai dapat meningkatkan keyakinan yang ada dalam diri individu, sehingga individu tersebut dapat bertahan untuk tidak mengkonsumsi zat narkoba dalam jangka waktu yang lebih lama (Torecillas, dkk., 2015).

Berdasarkan uraian di atas, dapat disimpulkan bahwa tinggi-rendahnya efikasi diri yang dimiliki individu (pecandu narkoba) memiliki peranan penting dalam mendukung proses pemulihan, seperti yang dijelaskan oleh Marlatt dan Gordon (Larimer, Palmer, \& Marlatt, 1999) dalam cognitive-behavioral model of relapse. Dengan mengacu pada fenomena tersebut, peneliti ingin mengungkap lebih jauh lagi terkait hubungan antara efikasi diri dan kecenderungan kambuh pada pecandu narkoba yang menjalani rehabilitasi di Yogyakarta.

\section{Metode}

\section{Subjek penelitian}

Subjek dalam penelitian ini adalah para pecandu narkoba yang sedang menjalani proses pemulihan di unit rawat jalan dan rawat inap di salah satu pusat rehabilitasi narkoba di Yogyakarta. Jumlah subjek adalah 59 orang yang terdiri dari 53 orang laki-laki dan 6 orang perempuan. Usia subjek berkisar antara 16 hingga lebih dari 45 tahun, dengan rentang pendidikan mulai dari Sekolah Dasar (SD) hingga jenjang pascasarjana (S2).

\section{Instrumen penelitian}

Metode pengumpulan data yang digunakan dalam penelitian ini terdiri dari dua macam skala, yaitu skala Kecenderungan Kambuh dan skala Efikasi Diri. Penelitian ini menggunakan skala Efikasi Diri yang disusun oleh peneliti sebelumnya, yaitu Noviza (2008) dan telah dimodifikasi oleh peneliti.

Skala Efikasi Diri disusun berdasarkan aspek-aspek efikasi diri mengacu pada teori yang dikembangkan oleh Corsini (1994). Aspek-aspek tersebut adalah kognitif, afeksi, seleksi, dan motivasi. Korelasi total antar item bergerak dari 0,341 sampai 0,774 dengan nilai Cronbach Alpha $(\alpha)$ sebesar 0,901 . Skala ini menyediakan empat alternatif jawaban, yaitu Sangat Sesuai (SS), Sesuai (SS), Tidak Sesuai (TS), dan Sangat Tidak Sesuai (STS). Pemberian skor bergerak dari angka 1 sampai dengan 4, pada pernyataan 
favorable nilai tertinggi 4 adalah untuk jawaban Sangat Sesuai (SS), 3 untuk jawaban Sesuai (S), 2 untuk jawaban Tidak Sesuai (TS), dan 1 untuk jawaban Sangat Tidak Sesuai (STS). Sebaliknya, pada pernyataan unfavorable nilai tertinggi 4 adalah untuk jawaban Sangat Tidak Sesuai (STS), 3 untuk jawaban Tidak Sesuai (TS), 2 untuk jawaban Sesuai (S), dan 1 untuk jawaban Sangat Sesuai (SS).

Sedangkan untuk skala Kecenderungan Kambuh menggunakan skala yang disusun oleh peneliti sebelumnya, yaitu Rozi (2016) dan telah dilakukan modifikasi oleh peneliti. Aspek-aspek pada skala ini adalah kekambuhan fisik, mental, dan emosional. Skala ini merupakan skala Likert dengan rentang skor satu sampai empat. Skor satu menunjukkan bahwa subjek sangat tidak setuju dengan pernyataan aitem skala. Skor dua menunjukkan bahwa subjek tidak setuju dengan pernyataan aitem. Skor tiga menunjukkan bahwa subjek setuju dengan pernyataan aitem, dan skor empat menunjukkan bahwa subjek sangat setuju terhadap pernyataan aitem skala. Skala kecenderungan kambuh terdiri dari aitem favorable dan unfavorable. Aitem favorable merupakan item yang mendukung dan mengarah pada variabel kecenderungan kambuh. Sedangkan aitem unfavorable berlawanan dengan variabel kecenderungan kambuh.

\section{Analisis data penelitian}

Analisis data yang dilakukan dalam penelitian ini menggunakan perhitungan statistik dengan bantuan software SPSS versi 22. Berikut ringkasan teknik analisis data dan taraf signifikansi:

Tabel 1. Analisis Data dan Taraf Signifikansi

\begin{tabular}{cccc}
\hline Analisis & Jenis Data & Statistik & Taraf Signifikansi \\
\hline Uji reliabilitas & Interval & Cronbach Alpha & $\alpha>0,50$ \\
& & Kolmogorov- & $\mathrm{p}>0,50$ \\
Uji normalitas & Interval & Smirnov & $\mathrm{p}<0,50$ \\
Uji linearitas & Interval & Analisis Varians & $\mathrm{p}<0,50$ \\
Uji hipotesis & Interval & Product Moment & \\
\hline
\end{tabular}

\section{Hasil}

Berdasarkan hasil analisis data, dapat diketahui bahwa variabel kecenderungan kambuh diperoleh $\mathrm{K}$-SZ = 0,664 dengan $\mathrm{p}=0,769(\mathrm{p}>0,05)$ dan pada variabel efikasi diri diperoleh $\mathrm{K}-\mathrm{SZ}=1,342$ dengan $p=0,055 \quad(p>0,05)$. Hal ini menunjukkan bahwa kedua variabel memiliki nilai Probabilitas (p) lebih besar dari 0,05. Kemudian, uji linieritas pada menunjukkan bahwa kedua variabel memiliki nilai $F=6,189$ dengan $\mathrm{p}=0,557(\mathrm{p}$ $>0,05)$, sehingga dapat dikatakan bahwa hubungan antara kedua variable bersifat linier.

Setelah terbukti bahwa sebaran data yang diperoleh adalah normal dan 
hubungan antar variabel linier, maka dilakukan uji terhadap hipotesis dengan teknik korelasi Product Moment dari Pearson. Perhitungan analisis korelasi
Product Moment menggunakan program SPSS 21.0 for windows, dan hasilnya adalah sebagai berikut:

Tabel 2. Analisis Korelasi Produt Moment

\begin{tabular}{lcccc}
\hline \multicolumn{1}{c}{ Variabel } & \multicolumn{3}{c}{ Pearson } \\
\cline { 2 - 5 } & dan & p & Keterangan \\
\hline $\begin{array}{l}\text { Efikasi diri } \\
\text { kecenderungan } \\
\text { kambuh }\end{array}$ & $-0,352$ & 0,006 & Signifikan \\
\hline
\end{tabular}

Hasil uji hipotesis antara variabel efikasi diri dan kecenderungan kambuh pada tabel di atas menunjukkan nilai koefisien korelasi sebesar $r=-0,352$ dengan nilai signifikan sebesar $\mathrm{p}=0,006(\mathrm{P}<0,05)$. Hal ini menunjukkan bahwa terdapat hubungan negatif yang kuat dan signifikan antara efikasi diri dan kecenderungan kambuh, dimana semakin tinggi efikasi diri yang dimiliki individu, maka semakin rendah peluang munculnya kecenderungan kambuh, dan begitu pula sebaliknya. Dengan demikian, maka hipotesis penelitian yang mengatakan bahwa terdapat hubungan negatif antara efikasi diri dan kecenderungan kambuh pada pecandu narkoba yang menjalani rehabilitasi diterima.

\section{Pembahasan}

Penelitian ini membuktikan bahwa terdapat hubungan yang kuat dan signifikan antara efikasi diri dan kecenderungan kambuh pada pecandu narkoba yang menjalani rehabilitasi, dengan arah hubungan negatif, dimana semakin tinggi efikasi diri pada pecandu narkoba maka akan semakin rendah kecenderungan kambuh yang akan dialami oleh pecandu narkoba, begitu sebaliknya. Secara umum, efikasi diri memiliki peranan penting dalam mendukung proses pemulihan pecandu narkoba. Adanya keyakinan diri yang ditanamkan dalam diri individu selama proses perawatan, dapat meningkatkan keberhasilan pecandu untuk meninggalkan zat narkoba tersebut. Kambuh merupakan permasalahan yang rumit dan butuh penanggulangan intensif. Sebagian besar pecandu narkoba memiliki potensi untuk kambuh. Kambuh atau kambuh akan narkoba merupakan suatu tantangan yang tak terpisahkan dari proses panjang menuju kesembuhan penuh. Setelah dilakukan pengambilan data di lapangan, peneliti menemukan adanya kondisi bahwa adanya tekanan atau sedikit masalah yang dialami oleh pecandu sangat berpengaruh terhadap suasana hati individu yang bersangkutan, hal tersebut yang mendorong individu untuk kembali mengkonsumsi narkoba, 
dengan anggapan bahwa dengan mengkonsumsi narkoba lagi, suasana hati individu akan menjadi lebih tenang dan bahagia.

Penelitian ini sejalan dengan temuan terdahulu bahwa efikasi diri memiliki peran penting sebagai prediktor dalam proses perawatan adiksi narkoba (Chong \& Lopez, 2008; Kadden \& Litt, 2011, Witkiewitz \& Marlatt, 2004). Bahkan temuan lain mempertegas bahwa efikasi diri menjadi faktor protektif agar individu terhindar dari penyalahgunaan narkoba (Chavarrie, Stevens, Jason, \& Ferrari, 2012). Oleh sebab itu, keyakinan akan kemampuan diri ternyata mampu membantu individu untuk menghindari zat adiktif maupun mempertahankan kondisi bebas memakai narkoba pascakecanduan.

Pernyataan tersebut diperkuat dengan hasil penelitian yang dilakukan oleh Ibrahim, Kumar, dan Samah (2011) yang menunjukkan bahwa terdapat hubungan negatif yang kuat dan signifikan $(\mathrm{r}=0,790$ dan $\mathrm{p}<0,05)$ antara efikasi diri dengan kecenderungan pecandu untuk mengalami kambuh. Disamping itu, penelitian lain yang dilakukan oleh Torecillas, dkk. (2015) dapat menjelaskan peran efikasi diri dalam memprediksi jumlah penggunaan narkoba yang dapat menim-bulkan kemungkinan kambuh. Hasilnya menunjukkan bahwa efikasi diri memiliki korelasi negatif dengan kuantitas penggunaan narkoba yang mengindikasikan bahwa peningkatan efikasi diri menurunkan kemungkinan penggunaan narkoba. Hal ini memperkuat bukti bahwa efikasi diri dapat menjadi indikator terjadinya kambuh melalui tingkat kemungkinan penggunaan narkoba.

Temuan atas hasil riset ini sejalan dengan beberapa penelitian terdahulu. Penelitian pertama dikemukakan oleh Nikmanesh, Baluchi, dan Motlagh (2017). Penelitian tersebut dilakukan di Iran dengan subjek sebanyak 166 orang dengan desain riset perbandingan antara dua kelompok. Hasilnya adalah ada perbedaan yang signfikan pada tingkat keyakinan efikasi diri pada kelompok partisipan yang mengalami kekambuhan adiksi dan kelompok yang tidak. Penelitian ini juga mencoba untuk melihat hubungan kausalitas antara keduanya dan semakin menguatkan pengaruh dari efikasi diri terhadap tingkat kekambuhan.

Riset lainnya oleh Abdollahi, Taghizadeh, Hamzehgardeshi, dan Bahramzad (2014) juga dilakukan di Iran pada subjek sebanyak 200 orang. Hasilnya adalah efikasi diri berkorelasi secara signifikan dengan kecenderungan kekambuhan. Selain itu, faktor-faktor demografis lainnya perlu menjadi catatan penting misalnya waktu pertama kali menggunakan narkoba, dosis yang dikonsumsi, prokrastinasi dalam mengikuti perawatan, status pernikahan, maupun pekerjaan.

Hasil riset dari luar negeri tersebut juga sesuai dengan penelitian yang 
dilakukan oleh Budiningsih, Djunaidi, dan Kustimah (2017) kepada mantan pasien terapi metadon yang pernah mengalami kekambuhan. Subjek menyatakan bahwa proses untuk berhenti total baik dari terapi metadon dan narkoba bukan merupakan hal yang mudah. Subjek harus melalui penurunan dosis metadon yang memiliki efek samping putus obat (withdrawl), subjek juga harus menghadapi ajakan teman-temannya yang pecandu aktif. Namun disamping itu, keyakinan dan semangat yang tinggi dari subjek untuk dapat lepas dari terapi metadon ataupun penggunaan narkoba membuat individu pada akhirnya berhasil sembuh total. Ketika individu dihadapkan dengan tekanan dari lingkungan maupun dari diri sendiri, individu tersebut berupaya sekuat mungkin untuk tidak kembali menggunakan narkoba sebagai jalan keluar. Keyakinan diri yang kuat ini merupakan indikator dari efikasi diri pada mantan pecandu narkoba.

Kemudian, hasil penelitian ini menunjukkan bahwa sumbangan efektif efikasi diri terhadap kecenderungan kambuh pada pecandu narkoba yang menjalani rehabilitasi sebesar 0,352. Hal tersebut menggambarkan bahwa efikasi diri memberikan pengaruh sebesar 35,2\% terhadap kecenderungan kambuh pada pecandu narkoba yang menjalani rehabilitasi. Sedangkan sisanya, 64,8\% dipengaruhi oleh faktor-faktor yang tidak terlibat dalam penelitian ini. Hal tersebut sejalan dengan cognitive-behavioral model of relapse yang menjelaskan bahwa rendahnya efikasi diri akan mempengaruhi pening-katan risiko terjadinya kambuh. Sebaliknya, menurut Marlatt dan Gordon, efikasi diri yang tinggi akan menurunkan resiko kambuh (Larimer, Palmer, \& Marlatt, 1999).

Berdasarkan sumbangan efektif di atas, maka efikasi diri bukanlah satusatunya variabel yang dapat mempengaruhi kecenderungan kambuh pada pengguna narkoba. Peneliti menemukan adanya kondisi bahwa sikap baik dari keluarga dan suasana rumah yang nyaman dapat meningkatkan motivasi pengguna untuk lepas dari zat narkoba secara total. Ketika pecandu mendapatkan perlakuan yang baik di rumah, dalam arti tidak dihakimi atau direndahkan, individu akan merasa dihargai dan termotivasi untuk melawan keinginan menggunakan narkoba kembali. Di samping itu, peneliti menemukan pecandu yang kambuh karena mengalami konflik dengan orangtuanya. Setelah ditelusuri, konflik tersebut berawal dari sikap orangtua subjek yang kurang baik, seperti kerap membentak dan menghakimi subjek. Hal ini membuat pecandu tersebut tidak betah di rumah, dan memilih untuk kembali bergaul dengan lingkungan pertemanannya yang lama, kemudian mengkonsumsi narkoba kembali. Terlihat bahwa pecandu sudah masuk pada tahap kekambuhan fisik, dimana individu tidak hanya memikirkan sensasi menggu- 
nakan narkoba, melainkan secara fisik sudah kembali mengkonsumsi narkoba.

Hal ini sejalan dengan hasil penelitian Hurriyati (2010) yang menunjukkan bahwa situasi di rumah yang tidak kondusif, seperti adanya konflik dengan orangtua (ayah), menyebabkan pengguna dapat melakukan koping maladaptif yaitu dengan menggunakan narkoba lagi. Selain itu, hasil penelitian tersebut juga menunjukkan bahwa persepsi dukungan sosial dapat mempengaruhi terjadinya kambuh.

Penelitian ini tentunya memiliki kelemahan, yaitu peneliti belum mempertimbangkan faktor-faktor lain dalam memilih subjek, seperti tingkat ketergantungan pengguna, lama penggunaan, alat yang digunakan, dan jenis zat yang dikonsumsi. Oleh sebab itu, faktor-faktor tersebut dapat dipertimbangkan oleh peneliti selanjutnya sebagai variabel penelitian.

\section{Simpulan}

Berdasarkan hasil analisis data kuantitatif yang diperoleh melalui penelitian ini, maka dapat ditarik kesimpulan bahwa terdapat hubungan negatif yang kuat dan signifikan antara efikasi diri dan kecenderungan kambuh pada pecandu narkoba yang menjalani rehabilitasi, artinya semakin tinggi efikasi diri pada pecandu narkoba maka akan semakin rendah kecenderungan kambuh yang akan dialami oleh pecandu narkoba.
Sebaliknya, semakin rendah efikasi diri maka akan semakin tinggi kecenderungan kambuh yang dimiliki oleh pecandu narkoba.

\section{Saran}

Berdasarkan hasil penelitian yang diperoleh, maka dapat dikemukakan beberapa saran sebagai berikut. Para pengguna narkoba di Rumah Sakit Jiwa X yang menjalani rehabilitasi, baik di unit rawat inap maupun rawat jalan diharapkan dapat berupaya untuk meningkatkan efikasi diri, seperti dengan mengamati dan mempelajari bagaimana cara-cara pengguna lainnya untuk berhasil lepas dari zat narkoba. Selama proses rehabilitasi berlangsung, sebaiknya para pengguna melakukan kegiatan-kegiatan yang menyenangkan dan hal-hal lain yang dapat mendatangkan ketenangan, baik secara fisik maupun psikologis. Selain itu, para pengguna diharapkan dapat bergaul di lingkungan pertemanan baru, yang dapat mendukung individu untuk terbebas dari narkoba. Selain itu, pihak Rumah Sakit Jiwa $\mathrm{X}$ diharapkan dapat membantu para pengguna narkoba untuk meningkatkan efikasi diri selama proses rehabilitasi berlangsung. Hal tersebut dilakukan sebagai upaya untuk meminimalisir munculnya kecenderungan kambuh. Bagi pihak keluarga diharapkan dapat memberikan dukungan penuh bagi para pengguna narkoba untuk meningkatkan efikasi diri dan memberikan suasana rumah yang 
nyaman, serta penuh kehangatan. Hal tersebut diperlukan untuk mendukung keberhasilan proses pemulihan pengguna narkoba.

Terakhir, peneliti selanjutnya diharapkan dapat memperoleh subjek yang lebih banyak dengan mempertimbangkan faktor-faktor seperti tingkat ketergantungan pengguna, lama penggunaan, alat yang digunakan, dan jenis zat yang dikonsumsi.

\section{Daftar Pustaka}

Abdollahi, Z., Taghizadeh, F., Hamzehgardeshi, Z., \& Bahramzad, 0. (2014). Relationship between addiction relapse and self-efficacy rates in injection drug users referred to Maintenance Therapy Center of Sari, 1391. Global Journal of Health Science, 6(3), 138-145.

Afiatin, T. (2008). Pencegahan penyalahgunaan narkoba dengan Program Aji. Yogyakarta: Gadjah Mada University Press.

Ariwibowo, K. (2013). Stigma negatif menjadi faktor utama mantan pecandu relapse. Badan Narkotika Nasional. Diakses dari http://dedihumas.bnn.go.id.

Badan Narkotika Nasional Republik Indonesia. (2007). Pencegahan penyalahgunan narkoba sejak usia dini. Jakartais[ep?

Bandura, A. (1997). Self efficacy: The exercise of control. USA: W.H. Freeman and Company

Bisono, T. (2008). My teens my inspiration. Jakarta: MeBook (Grup Puspa Swara)
Budiningsih, O. E., Djunaidi, A., \& Kustimah. (2017). Efektivitas relapse prevention therapy terhadap peningkatan self efficacy dalam menghadapi situasi risiko tinggi pemicu relapse pada pasien terapi metadon. Diunduh dari Universitas Padjajaran, Fakultas Psikologi website http://docplayer.info/41909621Fakultas-psikologi-universitaspadjadjaran-korespondensi.html

Chavarrie, J., Stevens, E. B., Jason, L. A., \& Ferrari, J. R. (2012). The effects of self-regulation and self-efficacy on substance use abstinence. Alcoholism Treatment Quarterly., 30(4), 422-432.

Chong, J., \& Lopez, D. (2008). Predictors of relapse for American Indian women after substance abuse treatment. American Indian and Alaska Native Mental Health Research, 14(3), 24-48.

Colondam, V. (2008). Pecandu dan integrasi sosial. Media Indonesia. Diunduh dari

http://www.mediaindonesia.com .

Corsini, R. J. (1994). Encyclopedia of psychology (2nd ed). Vol 3. New York: John Wiley and Son.

Ellya. (2017). Terus meningkat: Tahun 2017 pengguna narkoba mencapai 57 orang perharinya. Berita Jateng. Diunduh dari http://beritajateng.net.

Hadi, U. (2017). Awas! Yogyakarta urutan pertama pengguna narkoba terbanyak. Detik. Diunduh dari https://news.detik.com/beritajawa- tengah/d-3550865/.

Hawari, D. (1997). Alqur'an ilmu kedokteran jiwa dan kesehatan mental. Jakarta: Dana Bhakti Yasa. 
Hurriyati, M. A. (2010). Mengapa pengguna narkoba pada remaja akhir relapse? Humaniora, 1(2), 303-314

Ibrahim, F., Kumar, N., \& Samah, B. A. (2011). Self efficacy and relapsed addiction tendency: An empirical study. The Social Sciences, 6(4), 277-282

Infodatin. (2014). Situasi dan analisis penyalahgunaan narkoba. Kementrian Kesehatan Republik Indonesia. Diunduh dari http://www.depkes.go.id/folder/v iew/01/structure- publikasipusdatin-info-datin.html.

Jhonny. (2009). Tingkat relapse pengguna napza. Kompas. Diunduh dari http://www.kompas.com.

Kadden, R. M., \& Litt, M. D. (2011). The role of self-efficacy in the treatment of substance use disorders. Addict Behavior, 36(2), 1120-1126.

Larimer, M. E., Palmer, R. S., \& Marlatt, G. A. (1999). Relapse prevention: An overview of marlatt's cognitivebehavioral model. Alcohol Research and Health, 23(2), 151 - 160.

Marlatt, G. A., \& Gordon, J. R. (1985). Relapse prevention: Maintenance strategies in the treatment of addictive behaviors. New York: Guilford Press.

Banyak mantan pecandu napza kambuh (2008). Media Indonesia. Diunduh dari

http://www.mediaindonesia.com.

Muttaqin, A. (2007). Relapse opiat di rumah sakit ketergantungan obat Jakarta Tahun 2003-2005. Jurnal Kesehatan Masyarakat Nasional, 1(5), 203-207.
Nikmanesh, Z., Baluchi, M.H., \& Motlagh, A. A. P. (2017). The role of selfefficacy and social support on prediction of addiction relapse. International Journal of High Risk Behaviors and Addiction, 6(1).

Noviza. (2008). Hubungan antara efikasi diri dengan craving pada pecandu narkoba (Skripsi). Universitas Islam Indonesia, Yogyakarta.

Rozi, H. F. (2016). Pengaruh pelatihan self efficacy terhadap kecenderungan relapse pada pecandu narkoba di balai besar rehabilitasi badan narkotika nasional bogor. (Skripsi). Universitas Sebelas Maret, Surakarta.

Sasangka, H. (2003). Narkotika dan psikotropika dalam hukum pidana. Bandung: Mandar maju.

Torecillas, F. L., Cobo, M. A., Delgado, P., \& Uclés, I. R. (2015). Predictive capacity of self-efficacy in drug dependence and substance abuse treatment. Journal of Psychology and Clinical Psychiatry, 2(3), 73.

Witkiewitz, K., \& Marlatt, G. A. (20014). Relapse prevention for alcohol and drug problems: This was Zen, this is Tao. American Psychologist, 59(4), 224-235. 